Article

\title{
The Production of Food and Fiber: An Adaptation of CoP Features for Sustainable Water Use in Agribusiness
}

\author{
Keith D. Harris ${ }^{1, *}$ and Harvey S. James Jr. ${ }^{2}$ \\ 1 Department of Agricultural Economics, Kansas State University, 318 Waters Hall, Manhattan, KS 66506, USA \\ 2 Department Agricultural \& Applied Economics, University of Missouri, Columbia, MO 65211, USA; \\ hjames@missouri.edu \\ * Correspondence: kdharris@ksu.edu; Tel.: +1-178-5532-3918
}

Academic Editors: Alessio Cavicchi and Cristina Santini

Received: 16 August 2016; Accepted: 14 November 2016; Published: 18 November 2016

\begin{abstract}
Fresh water and arable land are essential for agricultural production and food processing. However, managing conflicting demands over water and land can be challenging for business leaders, environmentalists and other stakeholders. This paper characterizes these challenges as wicked problems. Wicked problems are ill-formed, fuzzy, and messy, because they involve many clients and decisions makers with conflicting values. They are also not solvable, but rather must be managed. How can agribusiness leaders effectively manage wicked problems, especially if they have little practice in doing so? This paper argues that a Community of Practice $(\mathrm{CoP})$ and its tripartite elements of domain, community and practice can be effective in helping businesses manage wicked problems by focusing on the positive links between environmental stewardship and economic performance. Empirically, the paper examines three agribusinesses to assess the extent in which CoP is used as a strategy for sustainable water management.
\end{abstract}

Keywords: agribusiness; community of practice; environmentalism; knowledge; relationships; wicked problems

\section{Personal Retrospective and Introduction}

A Senior Director of Corporate Purchasing for a large U.S. food company once led the firm's overall supply chain activities and strategies. This role required some traditional managerial qualities of visioning, directing, coordinating, and controlling resources for the purposes of organizational effectiveness. In the 1990s, the industry experienced significant changes of re-engineering, downsizing, outsourcing, and cost cutting. These programs changed the way the firm worked. The focus on creativity and inter-firm relationships had diminished. At the start of the new millennium, new challenges surfaced and proved more confusing, but critically important. These problems were ill-formed, fuzzy, and messy. The Senior Director's first response was to use practical knowledge, such as business acumen and experience, as well as tacit assumptions to cope with external threats that challenged the firm's profit plans. With a systematic and rational way of decision-making he theorized a solution, implemented an actionable plan and checked the results. The scientific manner and iterative process of managing the problem drove out any bias.

However, the challenges the company faced grew more complex. Many decisions related to business created a tension between social and economic goals. Across the organization, managers valued knowledge and believed it led to a reduction in the cost of goods sold-or a more dramatic consequence-the development of entirely new goods and services. On the one hand, practical knowledge became too subjective and insufficient to carry out the plan. On the other hand, the 
available scientific knowledge was too generalizable and not designed to solve a specific problem. The Senior Director found the underlying cause-and-effect structure itself under change. When the structure changes, all other insights previously learned are opened to justifiable scrutiny, leading to decisions that could not conform to scientific or tacit knowledge. Many problems the company faced were particularly complex-so complex that they could be described as wicked problems. The challenges have no precedence, thus the causes and effects are difficult to identify and model. It became apparent to the Senior Director that the company lacked the knowledge and relationships to predict and prescribe actions to its most difficult challenges. How can agribusiness leaders effectively manage wicked problems, especially if they have little practice in doing so?

\section{Introduction}

The human need for food requires fresh water and arable land for agricultural production and food processing. Land and water are fundamental parts of people's identity, social relations, livelihood strategies and economic well-being. Many aspects of the inextricable link of land and water to the production of food and fiber creates problems that agribusinesses may need to bring to the decision table. These problems often have something to do with the lack of congruence among environmental, social, and economic values, institutions, and practices that explain the irreversible processes of environmental degradation and our irreducible need of water. This is the hallmark of a wicked problem. Wicked problems occur in a social context and reflect the diversity among stakeholders influenced by dynamic, political, and biophysical factors. The interconnected social and economic risks for agribusinesses illustrate how a change in management resulting from the lack of access to clean water or a heightened concern with the extent by which water users deplete or pollute shared water resources will cause new constraints for land and water users. Water and land used to produce food and fiber are increasingly linked to making trade-offs among people, profit and planet. These problems are wicked because the definition of the issue is unclear and the solution to it is also unclear [1].

This paper focuses on phenomena facing leaders involved in navigating a wicked problem. Leadership often thinks in terms of decision-making that involves framing issues, implementing, monitoring, and enforcing plans; governance, which includes formal and informal rules through which stakeholders articulate interests; strategy entailing investing in a set of unique activities or processes designed to create a competitive advantage; and the development of professional skills, thus increasing the dynamic capability (cognitive and creative skills) of the individuals. The fundamental challenge to effectively managing wicked problems is to account for the varied interests and perspectives of different practitioners and identifying a path for employees to follow [2]. These types of problems require a different approach to leadership [3], forthcoming.

The research adapts the framework of Communities of Practice (CoP) to the problem of developing sustainable and actionable plans through knowledge development and practical applications. This is important because agribusiness firms are becoming increasingly aware that consumers care about the diverse economic risks arising from wicked problems [4]. For this reason, these firms have become more pro-active in addressing wicked problems, and mainstream initiatives started to compete with the traditional niche markets [5]. A wide range of internal and external factors led to increasingly published sustainability reports, which provide stakeholders with a picture of the firm's economic, social and environmental position [6,7].

Our claim is that the CoP framework is an ideal approach that an agribusiness manager can use to manage problems of sustainability, because it focuses on how relationships and knowledge affect responses to economic and non-economic uncertainties. The $\mathrm{CoP}$ framework merges aspects of knowledge and relationships, which provide managers the latitude to monitor a collaborative effort, generate new ideas, implement a plan, and assess progress. The CoP framework is important when dealing with an unwieldy problem, and it is used in this study to view the wicked problem from a very practical case. Thus, our objectives are as follows: First, we explain and identify a wicked problem that agribusinesses and environmentalists might deal with. Second, we argue that the CoP can be an 
effective collaborative governance structure for interacting with different stakeholders. In doing so, we establish the key variables of interest that define the CoP: the domain (a network of connections), the community (members engaging in joint activities to help one another), and the practice (codifying and circulating explicit knowledge, a new standard or a best practice). Third, we evaluate the how selected firms use the $\mathrm{CoP}$ as a strategy for environmental sustainability.

Recent literature on similar problems in agribusiness does not particularly reference the local and social aspects of addressing a wicked problem inasmuch as it advances national and global supply chain management and multi-stakeholder networks [8-10]. The informal and self-organizing nature of a CoP characterizes the diverse local stakeholders who connect grass root actions with rule-making and standard-setting organizations. For this purpose, we adapt and use a theoretical framework that invests in managing interactions, building knowledge and articulating relationships between individuals and organizations that lead to successfully managed societal values.

This paper contributes to the discussion on wicked problems in agribusiness with particular emphasis on the use of the CoP framework to management's challenge for the sustainable production of food and fiber. To the degree that practical experience is a necessary condition for actionable plans, inasmuch as the scientific knowledge plays a sufficient role when addressing the wicked problem. From an organizational point of view, the $\mathrm{CoP}$ features provide an approach that cuts across different societal actors and its spectrum of values and beliefs. It is particularly suited to allow a deliberative negotiation process as a major source of shared understanding, and it has the potential for collective learning, which arises through the process of gaining and sharing knowledge. Its outcome is to demonstrate a promising approach based on research grounded in actual experiences and everyday practices.

\section{The Nature of the Problem}

Wicked problems differ from complex problems in fundamental ways. While complex problems can be interconnected with other problems, wicked problems are fraught with significant interdependencies with other problems, so that efforts to deal with the wicked problem may affect, worsen or even create other problems elsewhere. As such, they require judgments of multiple stakeholders who often do not have shared values with respect to societal goals. As a result, solutions create both winners and losers, regardless of the management decisions made to deal with them. Unlike complex problems, which can have clearly defined and achievable solutions, wicked problems are never solvable - that is, it is not possible to know when or whether an end has been reached. Instead of solving wicked problems, efforts must be made to manage them. Thus, management decisions are judged based on whether they make things better or worse, not whether they solve or do not solve the problem. However, because of the interdependency aspect of wicked problems, indicators of "better" or "worse" are usually imprecise. Finally, wicked problems are dynamic and evolve over time, hence rendering any attempts for one-off solutions futile. Meeting the firm's objectives in the context of these challenges is akin to "changing a flat automobile tire while the vehicle travels at full speed" [11] - that is, performing a diagnosis of the problem and executing a solution without interrupting the business operations and protecting the environment.

A wicked problem must be appreciated for its range of conflicting perspectives lengthy list of relevant criteria that characterize wicked problems [12,13]. Four of these criteria we adopt as an efficient set to define the concept:

- Its solution is not true or false, but rather better or worse.

- Stakeholders have radically different frames of reference concerning the problem.

- The underlying cause-and-effect relationships related to the problem are complex, systemic and either unknown or highly uncertain.

- There is no template to follow when tackling a wicked problem, although history may provide a guide. Teams that approach wicked problems must literally make things up as they go along.

Land and water constraints fit the criteria quite well as the analysis will show. 


\section{An Industry's Wicked Problem}

Arable land and water are essential for agricultural production and food processing. Water availability is a pre-requisite for land use. Hence, water quality and land use are inextricably entwined in the production of food and fiber. To illustrate the impact that agriculture has had on land and water resources and to further motivate the interplay between land and water as a wicked problem, we review their uses for animal and crop production.

\subsection{Water}

From the field to the factory, producing food is perhaps the most water-intensive business on earth. The majority of the food sector's water use and water pollution footprint is associated with the agricultural supply chain. Irrigating crops and raising animals consumes roughly $70 \%$ of the world's freshwater [14].

The link between water, land, and agribusiness production is significant. In the U.S., agriculture irrigation and livestock accounted for approximately $40 \%$ of the nation's water withdrawals and $85 \%$ of total water consumption in 2013-greater than any other sector, both in total and as a share of water withdrawn [15]. This leads to declining stocks, which inevitably leads to higher and more volatile input and output prices, and an immediate impact on firm profitability. While water is often taken for granted, fresh water supplies are tightening as many new middle-class consumers replace grain in their diet with meat, which requires more water to produce.

The value chain for animal proteins requires a large amount of water to generate steam for hot water, washing and sanitation. In the U.S., bovine meat uses considerably more water to produce meat, calories, protein, and fat than other animal proteins and cereal grains. As an illustration, see Table 1, which reports on liters of water used to produce meat proteins and cereal grains [16].

Table 1. U.S. water consumption for meat and cereal grain production, period 1996-2005.

\begin{tabular}{ccccc}
\hline & Liter/kg & Liter/kcal & Liter/Gram Protein & Liter/Gram Fat \\
\hline Bovine meat & 15.415 & 10.19 & 112 & 153 \\
Pig meat & 5.988 & 2.15 & 57 & 23 \\
Chicken meat & 4.325 & 3 & 34 & 43 \\
Cereals & 1.644 & 0.51 & 21 & 112 \\
\hline
\end{tabular}

A further breakdown of water used for cereals and other crops used by agribusinesses is shown in Table 2 [17]. Agricultural crops, including cereal grains, use less water than animal proteins, but not all crops are the same in their use of water. The sum of the water used in the various steps in the production chain is referred to as "virtual water".

Table 2. Global water flows for the nine largest crops by international trade, period 1996-2005.

\begin{tabular}{ccc}
\hline Crop & $\begin{array}{c}\text { International Virtual } \\
\text { Water Flows }\left(\mathbf{M m}^{\mathbf{3}} \text { /Year) }\right.\end{array}$ & $\begin{array}{c}\text { Contribution to the Total International } \\
\text { Virtual Water Flows } \%\end{array}$ \\
\hline Seed cotton & 568.830 & 24.5 \\
Soybeans & 202.899 & 8.7 \\
Wheat & 200.619 & 8.6 \\
Cocoa beans & 86.895 & 3.7 \\
Coffee, green & 84.911 & 3.7 \\
Oil palm fruit & 70.945 & 3.1 \\
Maize & 68.785 & 3.0 \\
Rice, paddy & 98.585 & 3.0 \\
Sugar cane & 66.523 & 2.9 \\
\hline
\end{tabular}




\subsection{Land}

The production of cereal grains and animal proteins are land intensive. The agricultural area is divided into three categories: arable land ( $28 \%$ of the global agricultural area), permanent crops $(3 \%)$, and permanent meadows and pastures $(69 \%)$, which account for the largest share of the world's agricultural area [18]. Overall, meat production is responsible for $70 \%$ of global agricultural land, so a majority of the crops grown today are grown specifically for the production of meat [19]. Thus, animal proteins and cereal grains use a large share of water and land to produce the desired quantities of calories, protein, and volume. In addition, biofuels have an impact on access to land. The arable land per capita (ha in use per person) is projected to continue to decline through 2060 [20].

\subsection{The Wicked Problem}

An interruption in the use of either water or arable land will interfere with our ability to meet the future demand for food and fiber, thus creating food shortages to food security risks. However, farmers, agribusiness firms, and environmentalists are the de facto and principle managers of the most productive land and water resources on earth, and thus their decisions shape the surface of the planet in the coming decades. Their attempt to create a solution for land and water constraints has wide-ranging effects, and the extent to which their interests and values conflict turns the management of the problem into a wicked one. For example, many practitioners hold diverging, if not conflicting, terminal (or end-state) values. For some, ecological goals are foremost, whereas for others, profit and market objectives are paramount for survival. Their relationships may be a common means for the practitioner to reach ultimately incompatible agendas. Wicked problems arise largely from the interplay of a multiplicity of stakeholders with different definitions, capabilities, values, perceptions, and interdependent factors that comprise the problematic system (i.e., rivers) [21,22]. This is why we characterize water and land constraints in agriculture as a wicked problem. The resolution will require input from and judgments of multiple practitioners. The interests of a wide range of audiences will be affected, as well. Food and fiber production affects agricultural land-use and water resources. Settling on a common strategy of quality of water resources, potential land use, and land management fundamentally involves the interests of all practitioners.

Furthermore, the public continues to be interested in monitoring the quality and quantity of the nation's resources (such as water, land, air, plant and animal species) and in determining how human activities affect resources. However, there is significant controversy about the use of water and land in agricultural production, especially with respect to the production of meat protein. For example, some public commentators argue for a reduction in meat consumption because of the water and land resources required to produce meat protein. Others argue for a more moderate approach based on economic incentives for resource conservation that have been traditionally been referred to as "stewardship". Informed public policy and good resource stewardship depends on accurate assessments of environmental conditions and the economic costs and benefits of maintaining environmental quality.

The requirements for fresh water and arable land for food and fiber production present a threat to agribusiness in the production of cereal grains and animal proteins. The decision, either to act or not act on the wicked problem, requires attention. Key concerns include the potential for diverging corporate and public interests; policy and regulatory capture; privileging of economic over social perspectives; process inequities; displacement of existing water management priorities; and the risks of misguided interventions which undermine hydrological sustainability [23]. If left unchecked, emergency food and water shortages will cause often and sudden damage to food security. Agribusiness and modern environmentalism grounded on environmental protection can play a central role in mitigating the negative consequences of wicked problems and positioning the broad trajectory of production and processing to more desirable directions. 


\section{How Agribusiness and Environmentalism Might Develop a Sustainable Approach}

Megatrends in the food and agriculture industries have large transformative global forces that impact everyone on the planet. For instance, diverting farmland historically used for crops to biofuel production creates complexity, uncertainty, and accelerates a commodity price boom. The causes and solutions of this dilemma sparked a debate on whether crops should be used for food or fuel. Other megatrends, such as changing income and diets, climate change, increasing urbanization, and minimal ecological footprints, are incapable of a technical solution.

Agribusiness' industrial operations should strive towards a lower water footprint in industrial operations. Progress can be achieved by mitigating the degradation of water resources, nullifying evaporation losses, full water recycling and recapturing chemicals and heat from used water flows. The problem is not the fact that water is being used, but that it is not fully returned to the environment or not returned clean [24]. The insights gleaned from scholarly fields of strategic management and organization science considers how knowledge is created and makes a distinction between tacit and codified knowledge. Seminal work by Teece [25-27]) and Kogut and Zander [28] led to the knowledge-based view of the firm and they suggest that firms need to be efficient in scanning, choosing, acquiring and integrating knowledge from stakeholders. Knowledge and relationships have economic value. Many researchers maintain that, over time, wealth in the form of physical assets will diminish, while wealth in the form of knowledge assets will increase. The industrial age emphasized the exchange of goods and services; the coming age will emphasize the exchange of cognitive and emotional knowledge [29]. Without a set of unique activities to create, purchase, trade, or borrow against, the lack of knowledge and relationships would lead to a firm to underperform economically, environmentally and socially. Trends in employment relations, interdivisional relations, and inter-firm relations suggest the effect of growing knowledge intensity may be a trend toward greater reliance on alliances and strategic relationships, which cut across industries and link divergent value chains.

Conceiving an actionable approach requires viewing the problem from a pragmatic view. It involves merging knowledge with relationships. A pragmatic approach means the investigation of practice-based knowledge derived from methods of learning through practice, stories, rules of thumb, and imitation. Ostrom [30] provided a diagnostic framework for understanding the drivers of systems that have interactions across multiple scales. Other approaches include qualitative ones and encompass a wide variety of approaches: hermeneutics [31,32] as well as naturalistic inquiry, social constructionism, and new paradigm inquiry [33]; reflection-in-action [34]; and various forms of direct reference as qualitative research methods $[35,36]$. Bitsch also lists “... phenomenological research, ethnomethodology, ethnography, qualitative case study, participatory action research, and grounded theory" [37]. All of these approaches have at least some intellectual ancestry in pragmatism [38].

Each of these theoretical frameworks makes valuable suggestions about ways to frame wicked problems so that some action can be taken to make them better and not worse. Many of the insights gained from cumulative research in networks and community management are applicable to the wicked problems. These approaches arose out of experiences of failure of existing practices to deliver the desired outcomes, and the unintended effects of innovations [39]. However, the multitude of pragmatic approaches in the literature raises the question of precisely which pragmatic approach is of particular importance to wicked problems, and whether knowledge and relationships can be identified in the context of wicked problems. We argue that working in a participatory way for agribusiness and environmental organizations, such as community of practice, can capitalize on the local knowledge that exists between different organizations and stakeholders and facilitate the formation of improved management to solutions to wicked problems.

For the $\mathrm{CoP}$ to do this effectively, it must be responsive to the main elements of wicked problems, such as the need to identify strategies for managing rather than solving them, the involvement of multiple stakeholders with differing visions, interests and perspectives, the recognition that they are highly complex and interrelated and that they cannot be resolved through boilerplate templates. 


\subsection{What Is a CoP?}

A community of practice is a group of individuals or organizations that shares their interests and problems with a specific topic and gains a greater degree of knowledge of and expertise on a topic through their regular interaction [40]. The CoP framework helps to connect what we know with what we do when managing wicked problems. The perspective merges two elements: (1) the practical aspects of knowledge and (2) the importance of relationships with others who share an experience. Scholars have found that CoPs are highly effective in fostering the development, management and exchange of knowledge, information and resources within organizations [41,42].

Most CoPs have focused at grassroots and inter-organizational levels [43]. Some scholars have pointed to CoPs as relevant to understanding and managing wicked problems, such as Murgatroyd [44] and Southgate [45], who conceptualize school organization and teacher education as a wicked problem and point to CoPs as a means of managing them. Similarly, Hamilton [46] describes a consortium of businesses and non-profit organizations that function as a CoP to manage food system sustainability problems. Like Hamilton, we recognize that agribusiness is intimately familiar with the need to adapt to changing conditions-soil conditions, market conditions, credit market conditions, weather conditions, and more. Managers build a business case to support and drive their actions. Many environmental organizations realize the world's future demand for water depends on a different approach to successfully supply demand. CoP members share common interests in developing practices in a specific field and are distinguished by three primary features: domain, community, and practice.

\subsubsection{The Domain}

The domain of a CoP is presented in the common ground of economic and ethical responsibilities [47]. The domain consists of shared or common interest in developing practices in a specific field. The common interests promote a commitment to the domain. The domain can be contrasted with a purely informal network that only lasts as long as its members continue to find it beneficial for the cultivation of business relations that meet their professional needs. While expertise and experience can be important for fostering the domain, they are not necessary. Because wicked problems involve stakeholders with differing interests and perspectives, it is the identification of the common interests of members that matters most.

\subsubsection{The Community}

The community feature of a CoP refers to the activities, practices, and policies that support and foster positive connections and relationships among individuals, groups, organizations, and neighborhoods [48]. Often, a relationship perspective is found by the interactions of the practitioners, with whom they had little or no prior relationship, i.e., developing "weak ties" or "bridges" with partners [49]. Relationships are built on a foundation of mutual giving and receiving. The purpose of building relationships among members is to enable group members to learn from others. Because wicked problems involve complex and interconnected elements that can also be unknown or uncertain, obtaining information, insights and knowledge from stakeholders is essential to the identification of potential strategies for dealing with them. The effectiveness of potential strategies depends on the extent to which the community feature of the CoP creates and strengthens relationships and facilitates information sharing and learning.

\subsubsection{The Practice}

The practice is the way of engaging with other stakeholders and organizations in joint activities, sharing a scientific investigation or investigative procedure, adapting to changing circumstances, and renewing interests, commitment and relationships. It also involves the creation of a shared repertoire of resources, such as experience, knowledge, connections and skills. Because there is no common template for strategies in managing wicked problems, there is uncertainty in their effectiveness. Unanticipated changes in the environment and unforeseen eventualities can result 
in problems becoming worse rather than better. For this reason, having a toolkit of shared practices can be helpful for making needed adjustments.

The CoP framework is used in this study to view the wicked problem from a very practical or a 'real world' viewpoint. It consists of questions and exemplary issues to guide the case analysis. The framework is generic enough to cover the broad range of issues related to wicked problems. Therefore, the model supports our exploratory approach through its potential to uncover unanswered questions as well as unquestioned answers related to the different dimensions of analysis.

\subsection{Bridging CoP and Knowledge: The Doing-Knowing Gap}

CoPs hold a vision toward solving problems in contexts characterized by high interdependence and diverse knowledge. We adopt a view of knowledge as intricately connected with practice and conceptualized as an object instead of a process, meaning knowledge can be represented, written, and is a part of a routinized behavior [50]. There are five 'classes of knowledge' including, practical knowledge; intellectual knowledge (embracing scientific, humanistic, and cultural knowledge); pastime knowledge (news, gossip, stories, and the like); spiritual knowledge; and unwanted knowledge [51]. CoP brings a participatory perspective, which is grounded in a stakeholder's actual experience and everyday practice. A definition of $\mathrm{CoP}$ helps put into action how practitioners could join forces against wicked problems. They operate as social learning systems where practitioners connect to solve problems, share ideas, set standards, build tools, and develop relationships with peers and stakeholders. Wenger's definition expresses the importance of relationships and knowledge creation. The manner in which stakeholder's relationships integrate knowledge eventually forms the organizational processes needed to transform knowledge to create new capabilities or renew competencies. The relationship itself can occur in physical or virtual space. It exists for members to interact directly with one another [52]. Furthermore, bridging the doing-knowing gap includes relational spaces, which can be created through the informal designation of virtual space for ongoing dialogue. For instance, electronic communication technology in the form of electronic workflow, concurrent engineering, and document sharing helps to facilitate knowledge-linked organizations from an association of neighbors to an interest-oriented collective [53-55].

Knowledge creation and integration comes in the form of common agreements, such as a practitioner changing a production process into more sustainable alternatives to create new internal procedures or rules of conduct for the stakeholder. In order to facilitate the discussion on water sustainability between agribusiness firms and environmental groups, it is important for agribusinesses to have some basic understanding of how much water is consumed, evaporated, and/or polluted in a given amount of time. Likewise, environmental organizations will need to have a basic understanding of associated physical (freshwater shortages in the supply chain) and financial risks (increase costs or reduced revenues). Both parties need to stay open to challenges and dilemmas of the wicked problem.

\section{Research Methods}

We used the 2014 Ceres' Corporate Water Sustainability Report; website disclosures; financial annual reports; sustainability reports; and integrated annual reports, a combined environmental advocacy and annual financial report, for information on agribusinesses that documents stakeholder assumptions, preferences and views on water management. These sources allow us to evaluate the use of CoP as strategies for environmental sustainability. We looked for elements of the three things that characterize the $\mathrm{CoP}$ approach — the domain, the community and the practice—in order to determine the extent to which $\mathrm{CoP}$ is or is not used in selected firms. In doing so, we argue that $\mathrm{CoP}$ is not only an effective governance mechanism for dealing with wicked problems but also a temporary benchmark for assessing progress toward meeting the water management goals.

First, we studied corporate annual reports and environmental advocacy reports as sources to establish the domain feature of the CoP. The domain of $\mathrm{CoP}$ is presented in the common ground of economic and ethical interests as well as responsibilities. It underscores the importance of setting a strategic direction [56], creating a shared vision [57], articulating a strategic intent of the 
relationship [58], and setting goals to integrate financial and environmental measurements [59]. Therefore, we searched for evidence of strategic objectives that are set and ratified by its top management and recognized through governance committees. We looked for how local operations participate in the development, creation, and management of the best practices over the period of time in which a specific water project is deemed necessary. Then, we sought confirmation at the individual levels at which the practitioner community could work regarding water and land problems for genuine business and environmental decisions with strategic importance. We did this from three different perspectives of water degradation, including chemical, physical, and biological damage. This approach gives us an opportunity to understand the company's adaptation to water constraints-thus, revealing practices and establishing the domain of activity. We aimed mainly at analyzing what areas receive attention from firms; what are their main points of engagement; what reporting initiatives involve stakeholder firms.

Second, we examined how the agribusiness managers use the community feature, which emphasizes relationship building and shared connections. Firms do this through their disclosure reports directed to stakeholders, especially with respect to measuring social impact. For example, they use guidelines to ensure the responsible and sustainable use of local water resources, especially in light of their potential impact on local ecosystems and the right to water for local communities. We did this to develop objective inferences about water in any type of communication across the organizations (1) to become aware of the relationships between the environmentalist and agribusiness managers; (2) to publicize the quantitative and qualitative benefits to all stakeholders to motivate them and to promote inter organizational goals, develop standards, and increase interactions; and (3) to adopt a small set of common roles for managing knowledge and providing opportunities for sharing tacit knowledge among community members. Openness is required at different levels: the company, product, and facility level.

Third, we adopted stewardship and practice as analogous terms to explain the practical features of the CoP. The practice involves an action-oriented approach concerning governance of the relationship. It focuses on activities that develop the shared transfer of knowledge and practical tools for identifying and evaluating potential strategies for managing wicked problems. We divided this $\mathrm{CoP}$ feature into individual and organizational approaches to the wicked problem. We synthesized the goals of each into a single outcome of the CoP, effectively operating to develop and share best practices over the life of the relationship. The collective efforts role is to recognize areas of knowledge on which the CoP can focus its future efforts to develop and share knowledge and practices. With this approach, we can qualify environmental and economic performance measures for the stakeholders.

We examined three cases in each of the three features of a $\mathrm{CoP}$ and categorize, based on evidence, whether there are indicators for the use of that feature. Specifically, we considered 14 questions to guide our data collection of each dimension and support the findings of the research: three measuring the domain aspects, four measuring the community, and seven questions measuring the practice features of $\mathrm{CoP}$, which related to the policies, sharing ideas and values, promoting external expertise, and evaluation against the features of CoP. We then drew conclusions about the wicked problem's stakeholders based on whether there is or is not a preponderance of evidence for each feature. Additionally, we looked for potential evidence of professional and skill development.

\section{Results}

We analyze interactions through time between different partnerships and stakeholder's programs. Given the inclusion criteria, three cases were selected as representative cases of large companies that have to manage water as a part of their strategies for environmental sustainability using CoP features. At the same time, they have differences in sizes, and CoP experience. The diversity of size and experience in the CoP was also purposive, as it could be expected that larger and more experienced companies may have more knowledge and relationships. Table 3 gives an overview of the variability across the organizations involved in this research. 
Table 3. Comparison of three firm sizes and organizational systems related to land and water.

\begin{tabular}{lcccc}
\hline Organization & Employees/Members & $\begin{array}{c}\text { First Corporate Social } \\
\text { Responsbility Report or } \\
\text { Advocacy Report }\end{array}$ & $\begin{array}{c}\text { Water Use } \\
\text { Group } \\
\text { Memberships }\end{array}$ & $\begin{array}{c}\text { Water Use } \\
\text { Groups } \\
\text { Started }\end{array}$ \\
\hline Organization 1 & 75.000 & 2000 & 10 & 2 \\
Organization 2 & 45.000 & 2004 & 2 & 1 \\
Organization 3 & 5.000 & 1998 & 4 & 8 \\
\hline
\end{tabular}

Table 4 provides a summary of each organization and findings related to its use CoP feature. Organization 1 is the closest to possessing each $\mathrm{CoP}$ feature. This organization has the most experience with collaborations. It has community outreach programs aimed at ensuring a good relationship with local stakeholders on water-related topics. The relationships provide the basis for managing practitioner conflicts, and implementation of a solution. This can be explained because of the knowledge coming from the relationships directly affected their operations of the organization itself. Organizations 2 and 3 do not possess each characteristic. Specifically, the community and the domain features were weaker than others. The firms did not formulate recommendations or indicate leading practices or strengths. They provided less comparable information for collaborative decision-making, and they lacked consistent information across disclosure vehicles, including financial reports and sustainability reports. Organizations 2 and 3 do have a broader sample of collaborating members, invest in its operations, and share documents. Yet, both organizations operate less in the community and domain features of the CoP. The differences at the organizational and individual levels of the practice feature differ among all three organizations. Organization 2 had fewer links with stakeholder organizations, including developing opportunities for long-term shared value community organizations commitment. Organizations 1 and 3 were less different and operate within the CoP by means of a practical approach. This means that their involvement is based more on routines. For example, they operate within the current organizational rules and share knowledge.

Table 4. An organizational evaluation against the features of Community of Practice.

\begin{tabular}{cccc}
\hline & Organization 1 & Organization 2 & Organization 3 \\
\hline Domain-CSR and Advocacy Reports & & & \\
Disclosure/illustrating results to CoP members & $\mathrm{x}$ & $\mathrm{x}$ & $\mathrm{x}$ \\
Measurable social impact & $\mathrm{x}$ & $\mathrm{x}$ & \\
Measurable financial impact & $\mathrm{x}$ & $\mathrm{x}$ & $\mathrm{x}$ \\
Community-Connectedness & $\mathrm{x}$ & $\mathrm{x}$ & $\mathrm{x}$ \\
Transparency policies and standards & $\mathrm{x}$ & & \\
Promote access to inter-organizational networks & $\mathrm{x}$ & & $\mathrm{x}$ \\
Promote external expertise & $\mathrm{x}$ & $\mathrm{x}$ \\
Shared values face-to-face interactions & & $\mathrm{x}$ & \\
Practice-Stewardship & & $\mathrm{x}$ & $\mathrm{x}$ \\
Organizational level: & $\mathrm{x}$ & & $\mathrm{x}$ \\
Investment in operations & $\mathrm{x}$ & $\mathrm{x}$ \\
Governance structures with CoP leaders & & $\mathrm{x}$ & \\
Broader sample of CoP members & & $\mathrm{x}$ & \\
Individual level: & $\mathrm{x}$ & $\mathrm{x}$ & \\
Sharing expertise/ expert changes & $\mathrm{x}$ & & \\
Sharing documents and knowledge & & & \\
Electronic communities and forums & & & \\
Best practice control agent &
\end{tabular}

The informal and self-organized nature of a $\mathrm{CoP}$ often requires infrastructure and non-traditional ways of measuring its value and progress. We found that the organizational levels were governed and had established means to communicate formally and less informally. Its information technology 
infrastructure is designed to communicate electronically and disseminate best practices and knowledge among groups and through individuals.

Evidence found in stewardship and domain likely helped to establish strategic objectives, which are set and ratified by top management and governed through committees. Then, at the individual and organizational levels, the practitioner community could work on water and land problems as real opportunities and targets for genuine business decisions with strategic importance. Firms that participated in fewer CoPs exhibited more compliance related activities rather than creating new practices with stakeholders.

The results from this study are consistent with other $\mathrm{CoP}$ outcomes in terms of its recognition that the drive to participate is driven by the intrinsic benefits of the CoP membership: the opportunity to solve or mitigate problems, develop new ideas, and build relationships with peers with common problems. The fact that an effort was made to identify and engage local communities and other actors to increase their commitment to the formulated tasks was a deciding factor with regards to the successful results. The active participation of the local communities from the development of project ideas to their design and execution ensured that they were committed to supporting the final physical projects, maintaining the completed projects, and continuing to work on follow-up projects.

\section{Discussion and Managerial Implications}

The development of CoP initiatives in agribusiness is supported by the political and scientific demands for integrated, practitioner driven science, and is reflected in funders' requests for proposals [60]. For instance, the National Science Foundation increasingly requests proposals that include the social science impact as a criterion for selection of projects along with scientific excellence and intellectual merit [61]. The intent is to connect the proposed research with the broader effects on society. The National Institute of Food and Agricultural (NIFA) of the U.S. Department of Agriculture requests specific proposals directed at societal goals, such as rural agribusiness development and small farm prosperity, which face megatrends, such as, diverting farmland historically used for crops to biofuel production, changing income and diets, climate change, increasing urbanization, food versus food and minimal ecological footprints, that are incapable of a technical solution. The research-driven knowledge must be tested with industry peers.

In order to manage challenges, there is a need for divergent ideas and values across organizations. $\mathrm{CoP}$ is a representative example for an initiative of environmentalism and agribusiness engaged in a wicked problem. This analysis is so far only exploratory, and its methodology has certain limitations, which merit continued discussion. First, we derive our results from secondary data sources, namely the sustainability reports, and it is limited by the use of three cases and secondary data. We assume the reliability and consistency of this data for our study. Our results should not be generalized. However, we analyze a particularly interesting case of a collaboration that may hold substantial potential for approaching the wicked problem. The CoP shows that agribusinesses, environmentalists, and farmers in the food industry can operationalize their engagement through organizational partnerships designed to tackle the irreducible human need for fresh water and arable land. The CoP should help participants to evaluate and recognize the many different issues around farmers, environmentalists and agribusinesses.

This study explores the potential of firms to mitigate the wicked problems. Wicked problem thinking can be aligned with strategic planning theory. Instead of embracing one CoP as the best or the benchmark, it may be wiser for agribusiness managers to invest in managing interactions and articulating relationships between the firm's networks of different local, national, or global facilities. This suggests altering the role of agribusiness managers, while accounting for the varied interests and perspectives of different practitioners. The manager can promote knowledge sharing among community stakeholders, and act as strong stewards of the water and land resources they use. To effectively manage a problem is to consider the mind-set of the practitioners who are working to achieve an optimal solution or decide on a practical solution with an adequate level 
of acceptability. The CoP offers company managers a chance to develop business acumen, tacit, and scientific knowledge for an agribusiness firm. For example, leverage areas of direct control over its own manufacturing operations. That is, to continue to improve efficient water management, building on good progress to date, and to strive for the highest standards possible in water extraction, use and disposal. It can encourage farmers to promote good water management in agriculture. Beyond its core agribusiness activities, it can:

(1) Expand its efforts in sharing good water management practices in agriculture, particularly in its direct supply chain where it can have a significant impact. In some cases, these investments will also help provide clean water to rural communities.

(2) Offer its experience to the broader water management debate.

(3) Engage with a wide range of practitioners to improve the state of water management in communities where it operates.

(4) Focus will be on projects to improve local water management, working with others to establish better standards of water resource management, continuing ongoing efforts in education about water conservation, and participating in the debate on the impacts of agricultural policies, amongst others, on water resources.

Agribusinesses concede that water and land constraints are issues that must be addressed and have moved in ways to accommodate it within their strategies. Similarly, environmental groups must engage in strategic innovations to address environmental problems that result in operational efficiencies, new technologies, and marketable green products. Accordingly, we employ the concept of wicked problems to frame our research and a $\mathrm{CoP}$ to facilitate the process of arriving at empirical insights. A CoP represents an approach of bridging societal practitioners and merges both knowledge and relationships to encourage integrating environmental responsibility to create a practice that helps to solve the wicked problem.

\section{Research Directions}

While this paper has focused only on the land and water constraint aspects, a variety of other stakeholder issues warrant consideration including motivations, contingencies facilitating partnership building, changes in production and consumption, and collaborative learning processes. Land and water constraints are just some of the prominent examples of wicked problems and the CoP represents a social and economic avenue for research. A common thread for future inquiry seems to emerge. Agribusiness and environmentalism are social actors. The degree to which their knowledge and relationships are constrained or moderated depends on the economic and social purpose in which they operate.

Knowledge needs to be discovered and communicated in an explicit form. Relationships rest on the power of the division of labor, as a producer of knowledge depends on complementary arrangements for the communication and coordination of those efforts and their results. That is to say, relationships require the knowledge accumulation process to have the properties of a connected system. We suggest that wicked problems involving environmentalism and industrialism should be examined by means of an ethnological approach, thus interacting with many members to gain an in depth understanding of each feature's significance for a CoP. Future research might further extend our framework by specifying contingencies. Over time, as stakeholder objectives are met, change, or diverge, the practitioners may become less willing to broker and negotiate linkages between the firm and other domain practitioners, and potentially positively or negatively affect the firm's competitive advantage. We should also be mindful of the methods of effective engagement, which would include the development of management and leadership skills that are able to incorporate and integrate the knowledge, skills, resources, and perspectives from many agribusiness managers needed to undertake these problems. 
Acknowledgments: This article is supported by and contribution No. 17-114-J from the Kansas Agricultural Experiment Station, Manhattan, KS, Multistate Research Hatch Fund NC 1198 and MO-HASS0008.

Author Contributions: Keith D. Harris conceived and designed the study, collected and analyzed the data and co-wrote the paper. Harvey S. James Jr. co-wrote the paper. Both authors revised and approved the publication.

Conflicts of Interest: The authors declare no conflict of interest.

\section{References}

1. Batie, S. Wicked problems and applied economics. Am. J. Agric. Econ. 2008, 90, 1176-1191.

2. Peterson, H.C. An Epistemology for Agribusiness: Peers, Methods and Engagement in the Agri-Food Bio System. Int. Food Agribus. Manag. Rev. 2011, 14, 11-26.

3. Harris, K.; James, H. Cooperating to compete: Turning toward a community of practice. J. Bus. Strategy 2017, in press.

4. Fliess, B.; Lee, H.J.; Dubreuil, O.L.; Agatiello, O.R. CSR and Trade: Informing Consumers about Social and Environmental Conditions of Globalised Production; 2007 OECD Trade Policy Papers; Organization for Economic Co-Operation and Development: Paris, France, 2007.

5. Poetz, K.; Haas, R.; Balzarova, M. Emerging Strategic Corporate Social Responsibility Partnership Initiatives in Agribusiness: The Case of the Sustainable Agriculture Initiative. J. Chain Netw. Sci. 2012, 12, 151-165. [CrossRef]

6. Camillus, J.C. Strategy as a Wicked Problem. Available online: https://hbr.org/2008/05/strategy-as-awicked-problem (accessed on 13 November 2016).

7. Pérez-López, D.; Moreno-Romero, A.; Barkemeyer, R. Exploring the relationship between sustainability reporting and sustainability management practices. Bus. Strategy Environ. 2015, 24, 720-734. [CrossRef]

8. Hospes, O.; van der Valk, O.; Mheen-Sluijer, J.V. Parallel development of five partnerships to promote sustainable soy in Brazil: solution or part of wicked problems. Int. Food Agribus. Manag. Rev. 2012, 15, 39-62.

9. Bos, J.M.; Blok, V.; van Tulder, R. From confrontation to partnerships: The role of a Dutch Non-Governmental Organization in co-creating a market to address the issue of animal welfare. Int. Food Agribus. Manag. Rev. 2013, 16, 69-75.

10. Touboulic, A.; Walker, H. Love me, love me not: A nuanced view on collaboration in sustainable supply chains. J. Purch. Supply Manag. 2015, 21, 178-191. [CrossRef]

11. Uarich, S. Personal Communication Smithfield Foods Weekly Supply Chain Conference. Unpublished work. 2005.

12. Rittel, W.J.H.; Webber, M. Dilemmas in a General Theory of Planning. Policy Sci. 1973, 4, 155-169. [CrossRef]

13. Conklin, J. Wicked Problems \& Social Complexity; CogNexus Institute: Napa, CA, USA, 2006.

14. Food and Agriculture Organization of the United Nations. 2015. Available online: http://www.fao.org/ home/en/ (accessed on 30 June 2016).

15. USDA. United States Department of Agriculture Economic Research Service-Irrigation \& Water Use. 2015. Available online: http:/ / www.ers.usda.gov/topics/farm-practices-management/irrigation-water-use.aspx (accessed on 3 July 2016).

16. Mekonnen, M.M.; Hoeskstra, A.Y. National Water Footprint Accounts: The Green, Blue and Grey Water Footprint of Production and Consumption; Value of Water Research Report Series No. 47 UNESCO-IHE; Institute for Water Education: Delft, The Netherlands, 2010.

17. Mekonnen, M.M.; Hoekstra, A.Y. The Green, Blue and Grey Water Footprint of Crops and Derived Crop Products. Hydrol. Earth Syst. Sci. 2011, 15, 1577-1600. [CrossRef]

18. Fao, F. Statistical Yearbook 2013: World Food and Agriculture. Available online: http://www.fao.org/ docrep/018/i3107e/i3107e00.htm (accessed on 15 November 2016).

19. Fiala, N. Measuring Sustainability: Why the Ecological Footprint Is Bad Economics and Bad Environmental Science. Ecol. Econ. 2008, 67, 519-525. [CrossRef]

20. Popp, A.; Rose, S.K.; Calvin, K.; van Vuuren, D.P.; Dietrich, J.P.; Wise, M.; Stehfest, E.; Humpenöder, F.; Kyle, P.; van Vliet, J.; et al. Land-Use Transition for Bioenergy and Climate Stabilization: Model Comparison of Drivers, Impacts and Interactions with Other Land Use Based Mitigation Options. Clim. Chang. 2014, 123, 495-509. [CrossRef]

21. Peterson, H.C. Transformational Supply Chains and "The wicked Problem" of Sustainability: Aligning Knowledge, Innovation, Entrepreneurship, and Leadership. J. Chain Netw. Sci. 2009, 9, 71-82. [CrossRef] 
22. Turnpenny, J.; Lorenzoni, I.; Jones, M. Noisy and Definitely Not Normal: Responding to Wicked Issues in the Environment, Energy and Health. Environ. Sci. Policy 2009, 12, 347-358. [CrossRef]

23. Hepworth, N. Open for Business or Opening Pandora's Box? A Constructive Critique of Corporate Engagement in Water Policy: An Introduction. Water Altern. 2012, 5, 543-562.

24. Hoekstra, A.Y. The Water Footprint of Modern Consumer Society. Available online: https:/ /books.google.com/books?hl=en\&lr=\&id=RD4khfq_7vkC\&oi=fnd\&pg=PP2\&dq=water+ management+Hoekstra\&ots=IT_QYc9hzA\&sig=oFa7511NJ8n2QPE_cmg940ifkf4 (accessed on 10 June 2016).

25. Teece, D.J. The Market for Know-How and the Efficient International Transfer of Technology. Ann. Am. Acad. Political Soc. Sci. 1981, 458, 81-96. [CrossRef]

26. Teece, D.J. Towards an Economic Theory of the Multiproduct Firm. J. Econ. Behav. Organ. 1982, 3, $39-63$. [CrossRef]

27. Teece, D.J. Explicating dynamic capabilities: The nature and micro foundations of (sustainable) enterprise performance. Strateg. Manag. J. 2007, 28, 1319-1350. [CrossRef]

28. Kogut, B.; Zander, U. Knowledge of the Firm, Combinative Capabilities, and the Replication of Technology. Organ. Sci. 1992, 3, 383-397. [CrossRef]

29. Rifkin, J. The Age of Access: The New Culture of Hyper Capitalism. Where All of Life Is a Paid-for Experience; Tarcher: New York, NY, USA, 2000; Volume 33, pp. 40-51.

30. Ostrom, E. A General Framework for Analyzing Sustainability of Social-Ecological Systems. Science 2009, 325, 419-422. [CrossRef] [PubMed]

31. Gummesson, E. Qualitative Methods in Management Research; Sage Publications: Beverly Hills, CA, USA, 1991.

32. Jankowicz, A.D. Fully Structured Techniques. In Business Research Projects; Springer: New York, NY, USA, 1995; pp. 222-254. Available online: http://link.springer.com/chapter/10.1007/978-1-4899-3386-7_12 (accessed on 15 July 2016).

33. Easterby-Smith, M.; Thorpe, R.; Lowe, A. Management Research: An introduction; SAGE: Thousand Oaks, CA, USA, 1991; p. 1.

34. Schön, D.A. Knowing-in-Action: The New Scholarship Requires a New Epistemology. Chang. Mag. High. Learn. 1995, 27, 27-34. [CrossRef]

35. Cassell, C.; Symon, G. Qualitative Research in Work Contexts. In Qualitative Methods in Organizational Research: A practical Guide; Cassell, C., Symon, G., Eds.; Sage: London, UK, 1994; pp. 1-13.

36. Ghauri, P.N.; Gronhaug, K. Research Methods in Business Studies: A Practical Guide, 1st ed.; Prentice Hall: Upper Saddle River, NJ, USA, 1995.

37. Bitsch, V. Qualitative Research: A Grounded Theory Example and Evaluation Criteria. J. Agribus. 2005, 23, 75-91.

38. Johnson, G.L. Economics and Ethics. Centen. Rev. 1986, 30, 69-108.

39. Oreszczyn, S; Lane, A.; Carr, S. The Role of Networks of Practice and Webs of Influencers on Farmers' Engagement with and Learning about Agricultural Innovations. J. Rural Stud. 2010, 26, 404-417. [CrossRef]

40. Lave, J. Situating Learning in Communities of Practice. Perspect. Soc. Shared Cognit. 1991, 2, $63-82$.

41. Fontaine, M.A.; Millen, D.R. Understanding the Benefits and Impacts of Communities of Practice. In Knowledge Networks: Innovation through Communities of Practice; Hildreth, P.M., Kimble, C., Eds.; Idea Group: Hershey, PA, USA, 2004; pp. 1-13.

42. Du Plessis, M. The strategic drivers and objectives of communities of practice as vehicles for knowledge management in small and medium enterprises. Int. J. Inf. Manag. 2008, 28, 61-67. [CrossRef]

43. Valdivia, C.; Seth, A.; Gilles, J.; García, M.; Jiménez, E.; Cusicanqui, J.; Navia, F.; Yucra, E. Adapting to Climate Change in Andean Ecosystems: Landscapes, Capitals, and Perceptions Shaping Rural Livelihood Strategies and Linking Knowledge Systems. Ann. Assoc. Am. Geogr. 2010, 100, 818-834. [CrossRef]

44. Murgatroyd, S. "Wicked Problems" and the Work of the School. Eur. J. Educ. 2010, 45, 259-279. [CrossRef]

45. Southgate, E.; Reynolds, R.; Howley, P. Professional Experience as a Wicked Problem in Initial Teacher Education. Teach. Teach. Educ. 2013, 31, 13-22. [CrossRef]

46. Hamilton, H. Sustainable Food Lab Learning Systems for Inclusive Business Models Worldwide. Int. Food Agribus. Manag. Rev. 2013, 16, 33-38.

47. Carroll, A.B. A Three-Dimensional Conceptual Model of Corporate Performance. Acad. Manag. Rev. 1979, 4, 497-505. 
48. Wenger, E. Communities of Practice: A Brief Introduction. 2011. Available online: https://scholarsbank. uoregon.edu/xmlui/handle/1794/11736 (accessed on 31 January 2016).

49. Granovetter, M.S. The Strength of Weak Ties. Am. J. Sociol. 1973, 78, 1360-1380. [CrossRef]

50. Nicolini, D.; Gherardi, S.; Yanow, D. Knowing in Organizations: A Practice-Based Approach; ME Sharpe: Armonk, NY, USA, 2003; Available online: https://books.google.com/books?hl=en\&lr=\&id=18ceLSRePhoC\&oi= fnd\&pg=PA3\&dq=Nicolini\&ots=S7hkxb0G-w\&sig=hr_tRyEN4MbQ7H2AzL5-sgDnV4g (accessed on 10 May 2016).

51. Machlup, F. The Production and Distribution of Knowledge in the United States; Princeton University Press: Brighton, MA, USA, 1962; Volume 278.

52. Veldhuizen, M.; Blok, V.; Dentoni, D. Organisational Drivers of Capabilities for Multi-Stakeholder Dialogue and Knowledge Integration. J. Chain Netw. Sci. 2013, 13, 107-117. [CrossRef]

53. Gumpert, G. The Media: Structural Changes and Personal Choice. ETC Rev. Gen. Semant. 1987, 44, $174-179$.

54. Badaracco, J. The Knowledge Link: How Firms Compete through Strategic Alliances; Harvard Business Press: Brighton, MA, USA, 1991; Available online: https://books.google.com/books?hl=en\&lr=\&id= dw9i6ZkfhZEC\&oi=fnd\&pg=PR9\&dq=electronic+communication+Badaracco\&ots=tcc-P1E0zd\&sig=TbLRldMDG4lWYxgIIUUqWIvcHg (accessed on 5 May 2016).

55. Rheingold, H. The Virtual Community: Finding Connection in a Computerized World; Addison-Wesley Longman Publishing Co. Inc.: Boston, MA, USA, 1993; Available online: http://dl.acm.org/citation.cfm?id=529182 (accessed on 21 May 2016).

56. Mintzberg, H. The Case for Corporate Social Responsibility. J. Bus. Strategy 1983, 4, 3-15. [CrossRef]

57. Kotter, J.P. Leading Change: Why Transformation Efforts Fail. Harv. Bus. Rev. 1995, 73, 59-67. [CrossRef]

58. Hamel, G.; Doz, Y.L.; Prahalad, C.K. Collaborate with Your Competitors and Win. Harv. Bus. Rev. 1989, 67, 133-139.

59. Meckenstock, J.; Barbosa-Póvoa, A.P.; Carvalho, A. The Wicked Character of Sustainable Supply Chain Management: Evidence from Sustainability Reports. Bus. Strategy Environ. 2015. [CrossRef]

60. Molls, P.; Zander, U. Managing the Interface: From Knowledge to Action in Global Change and Sustainability Science. In Trans; Lindemann, S., Wood, P., Eds.; German Federal Ministry of Education and Research: Munich, Germany, 2006.

61. Pielke, R.A., Jr. The Honest Broker: Making Sense of Science in Policy and Politics; Cambridge University Press: Cambridge, UK, 2007.

(C) 2016 by the authors; licensee MDPI, Basel, Switzerland. This article is an open access article distributed under the terms and conditions of the Creative Commons Attribution (CC-BY) license (http:/ / creativecommons.org/licenses/by/4.0/). 